
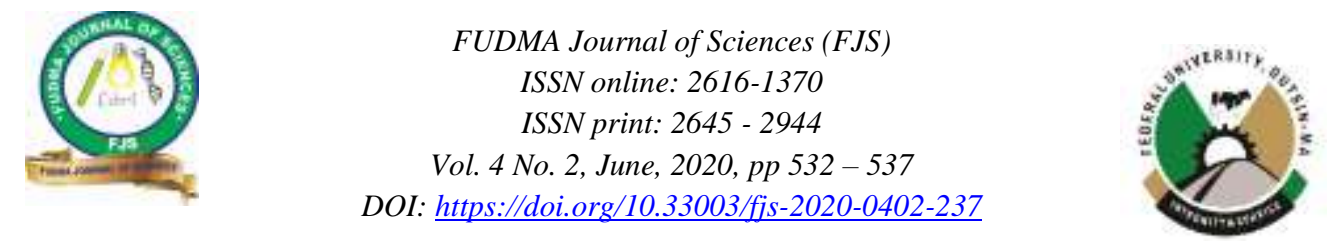

\title{
ETHNOBOTANICAL SURVEY OF MEDICINAL PLANTS USED IN THE TREATMENT OF CANCER IN DUTSIN- MA LOCAL GOVERNMENT AREA OF KATSINA STATE, NIGERIA
}

\author{
*Okunola, O. J., Ali, T. and Bello, O. M. \\ Department of Applied Chemistry, Federal University Dutsin-ma, Katsina State, Nigeria \\ *Corresponding author's email: ookunola@ fudutsinma.edu.ng
}

\begin{abstract}
Ethnopharmacological surveys showed that herbal remedies and their products are mostly preferred type of alternative and complementary medicine (ACM) globally. In Dutsin-Ma Local Government Area (LGA) like other places herbal remedies are popularly employed against many ailment including tumor and cancer. Therefore, this study aimed to report and document the ethnobotanical survey of the plants used in the management of tumor and cancer in Dutsin-Ma Local Government Area of Katsina State, Nigeria. Traditional medicine practitioners (TMPs) living within the area of study were cross-examined by employing questionnaires forms and key informant survey. Forty-two (42) different plant species were discovered to be employed against cancer and tumor management. The results obtained showed the parts of plant used for the herbs include; roots (4), bark (10), whole plant (13), seeds (5), fruits (3), stem (1) and leaves (6). The plant families Leguminosae caesalpinoideae and Leguminosae mimosoideae appeared more in the ethno-surveyed plant list though other families are involved. Many of these plants are mix together as storehouses for active compounds which may be good template for cancer and tumor management. The preparation of the remedies include; grinding to powder form then dispersing in either water or milk for drinking, or either mix with shear butter or water and administered on the affected part of the body. The reports showed that the herbal remedies indentified are effective for the treatment of cancer in Dutsin-Ma local government area. Hence, it is imperative for ethnobotanists and chemists to establish the toxicity and efficacy of these plants
\end{abstract}

Keywords: Ethnobotanical, Survey, Cancer, Dutsin-Ma, Leguminosae caesalpinoideae

\section{INTRODUCTION}

Cancer is one of the principal cause of death globally, world's second leading cause of death and is responsible for reported deaths of 9.6 million in 2018. About one in six deaths worldwide were due to cancer. Approximately $70 \%$ of cancer deaths happen in low- and middle-income countries. (WHO, 2018). In last few years, reports of deaths from cancer ailments have continued to send cold shrills down the spines of many Nigerians. There is a pervasive concern and apprehension over the high incident rate of the disease amongst people of various strata of the society. Cancer is no respect for age or social status, the young and the old as well as the poor and the rich are susceptible to infection (Independent News, 2017).World Health Organization (WHO) report indicates that Nigeria has an estimated 10,000 cancer deaths annually, with no few than 250,000 new cases being recorded yearly. Judging by the high number of cases recorded across the country on annual basis, cancer has gradually become an endemic plague requiring a national emergency (Independent News, 2017).

Good health is the most important thing and the basis for happiness in people. The employment of herbal medicine against diseases and illness is a constituent of body balance systems and has turnout to be an integral part of people's cultural life and traditional heritage (Amupitan, 2013). Since its development, many groups have therefore developed new traditional systems exploiting locally available plant and animals resources to address health issues (Adesina, 2008).

Herbal remedies have long been accepted by human as one of the oldest types of medicine (Eisenberg et al., 1998). Despite advances in modern medicine many people in third world countries often depend on traditional therapeutic methods and medicinal plants for their daily healthcare needs (Ojewole, 2004).

Moreover, there is little report on the vast indigenous unexplored medicinal plants of Dutsin-Ma, Local Government Area (LGA), Katsina State despite its rich ethnomedicinal heritage. This calls for survey of medicinal plants of the study area in order to generate a data base for anti-cancer plants. The need for cheap and affordable treatment approaches to fulfill the primary health care needs has increased demand for herbal drugs among people in rural areas.

Therefore, in order to obtain this knowledge, ethnobotanical survey needs to be enforced, the cultivation, uses and conservation of plants continues to be a significant part of people's live, so the need for this report. The research 
subsequently gives more details to increasing awareness about the successful use of these local plants species.

\section{MATERIALS AND METHODS}

Dutsin-Ma is the headquarters for Dutsin-Ma LGA in Katsina State, Nigeria. The town lies within the $12^{\circ} 27^{\prime} 18^{\prime \prime} \mathrm{N} 7^{\circ} 29^{\prime} 29^{\prime \prime} \mathrm{E}$ and covers an area of $527 \mathrm{~km}^{2}$ (203 sq metres). About nineteen (19) districts comprises of this LGA. A preliminary study was carried out to identify the traditional medicine practitioners (TMPs) in the local government using the traditional medicine Union leader. A total number of twenty (20) traditional medicine practitioners (TMPs) were identified in sixteen (16) districts out of the nineteen (19) district in the LGA as shown in Figure 1. Hence, a well designed structured and open-ended questionnaire was administered to the TMPs to derived information regarding plants used for treatment of cancer, mode of preparation and administration using guided dialogue techniques in Hausa language - local dialect of the TMPs. The designed questionnaire was validated by the discussant groups which include experts in the research area. Plants used by the TMPs are collected and botanically identified. The plants identification was done by Umar Shehu Gallah herbarium consultant and plant taxonomist at Deaprtment of Biological Science, Ahmadu Bello University, Zaria, Nigeria. Voucher specimens of the plants were deposited in the herbarium. Data obtained from the questionnaires were analyzed using descriptive statistics.

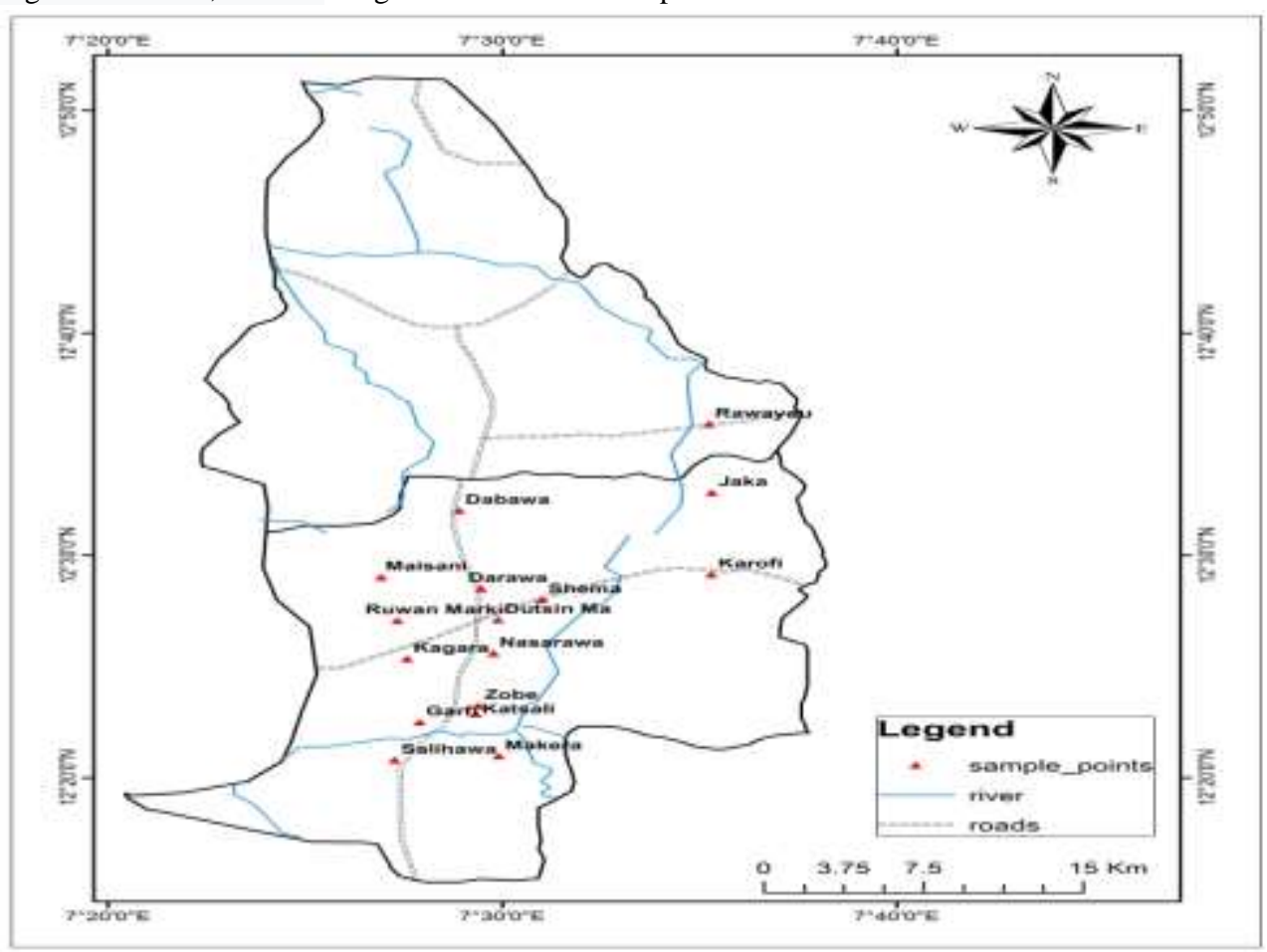

Figure 1: Map of Dutsin-Ma LGA showing the sampling points.

\section{RESULTS AND DISCUSSION}

A total of 42 plant species belonging to 32 families were used as medicinal plants in the study area as shown in Table 1. From Figure 2 Leguminosae, caesalpinoideae and mimosoideae occurred more but the incidence of other families also indicates the significance of all those families as sources of useful organic compounds that can be investigated for drugs in cancer management. However, leguminosaecae salpinoideae have been documented to be used for the treatment of cancer among others (Burkil, 1995; Deeni and Sadiq, 2002; Olapade, 2002; Soladoye et al., 2010; Traore, 2000). Fabaceae or Leguminosae is with over 600 genera and 17900 species, it is renown to be the third largest family of flowering plants (angiosperms), followed by Orchidaceae and Asteraceae or Compositae. Plants of this family are rich in phytoconstituents which make them effective therapeutic agents for various diseases.Secondary metabolites from the plants of this family have been reported for their cytotoxicity against various human cancer cells (Kumar et al., 2011; Rayanil et al., 2011). The family leguminosae is also divided into 3 subfamilies papilionodae, caesalpinioideae and mimosoideae. Leguminosaecae salpinioideae and mimosoideae are reputed to have diverse characteristics and activities i.e. anticancer (Salem et al., 2011)

Also, Table 1 describes the parts of plant used for the herbs, these include; roots (4), bark (10), whole plant (13), seeds (5), fruits (3), stem (1) and leaves (6). This corroborate with similar study reported by Soladoye et al. (2010), that quite a number of 
plant parts in particular the leaves, roots, barks and seeds were found to be efficient in cancer management.

The popular parts of plant species employment in the treatment of cancer is the whole plant $(31 \%)$ followed by the bark $(24 \%)$, leaves $(14 \%)$, seed $(12 \%)$, roots $(10 \%)$, fruits $(7 \%)$ and lastly the stem $(2 \%)$ as shown in Figure 3. Fresh or air-dried parts of the plants were employed by majority of the TMPs. Sustainable methods of harvesting were employed by the TMPs to protect the medicinal plants from obliteration and overutilization (Ochwang'I et al., 2013).
From this study, 42 plants belonging to 32 families employed in the treatment of cancer and tumour in Dutsin-Ma L.G.A. Some of these medicinal plants have been reported in the treatment of cancer notably amongst these are Securidaca longipedunculata Fresen, also called violet tree in English. Ngulde et al. (2019) reported the activity of ethanol extract of $S$. longipedunculata against Brain Tumor (U87) Cells. The ethanol extract of the root bark of S. longipedunculata inhibited proliferation of U87 cell line and induced apoptosis by cleavage of PARP (Ngulde et al., 2019).

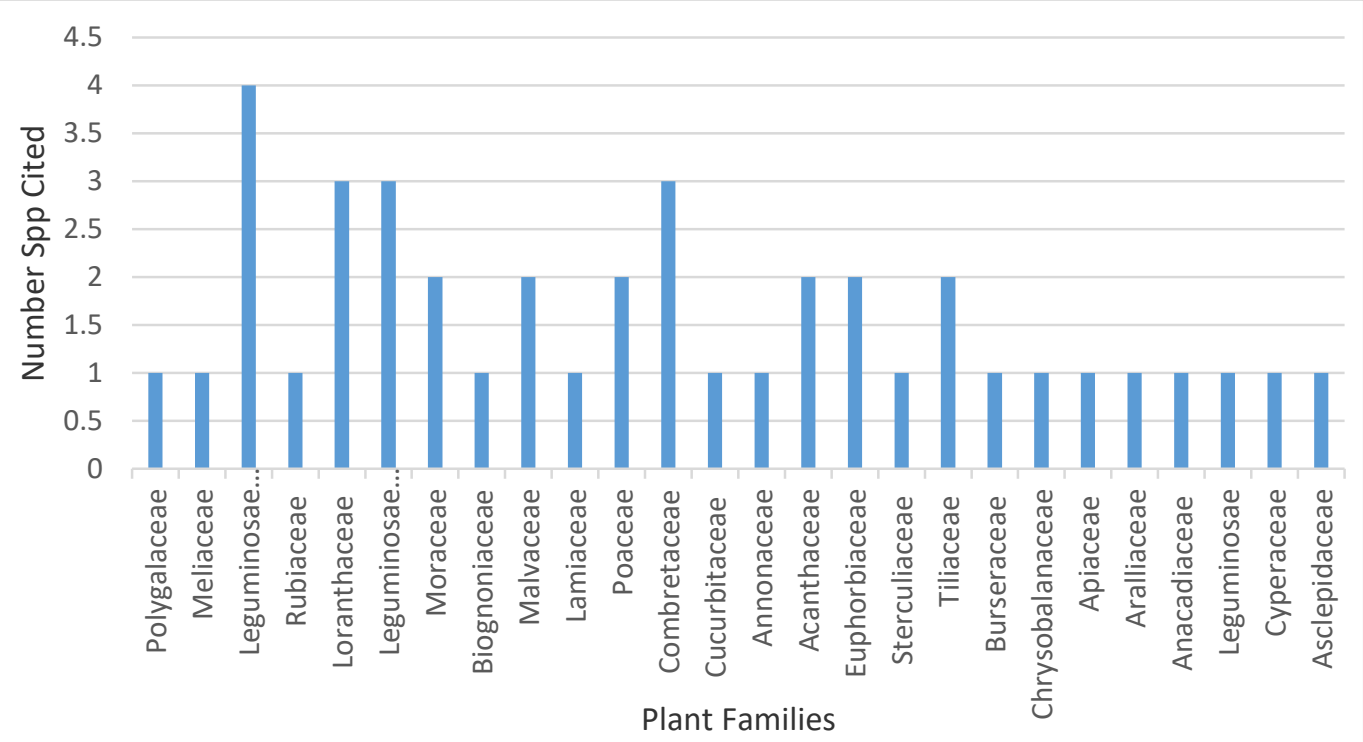

Figure 2: Frequency of plant families employed against Cancer in Dutsin-Ma L.G.A

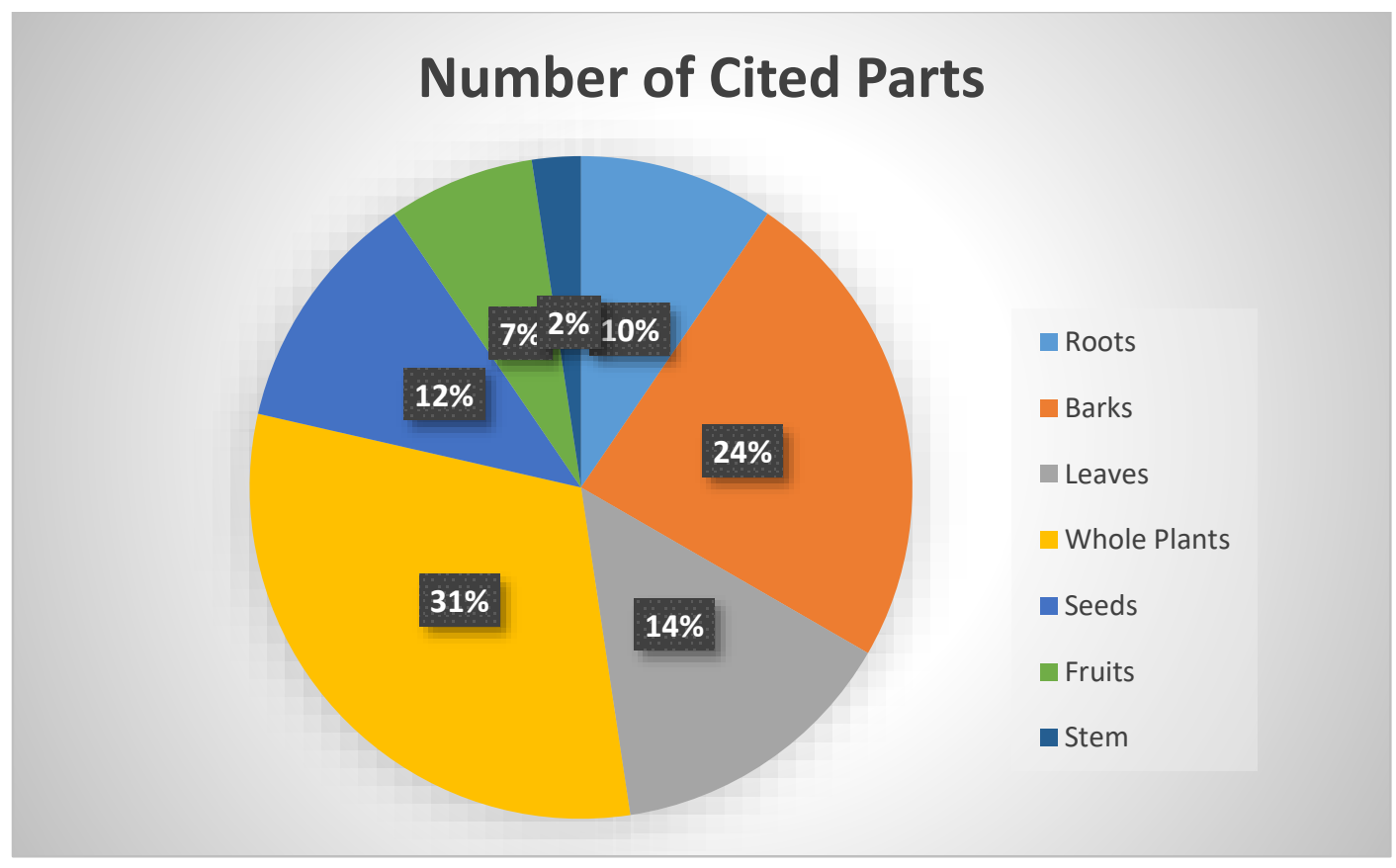

Figure 3: Frequency of parts from the medicinal plants surveyed 
The crude extract and isolated constituents of the Dichrostachys cinerea bark was also reported against multifactorial drugresistant Cancer Cells by Mbaveng et al., (2019). The betulinic acid and 6-hydroxy-2-(4-hydroxyphenyl)-4H-chromen-4oneisolated from $D$. cinerashowed cytotoxic effects towards the 9 tested cancer cell lines with $\mathrm{IC}_{50}$ below $50 \mu \mathrm{M}$ (Mbaveng et al.,2019). Tatematsu et al. (1991) reported two cytotoxic secondary metabolites isolated from Securinega virosa i.e. virosecurinine and viroallosecurinine. These isolated alkaloids showed significant cytotoxicity with $\mathrm{ED}_{50}$ of 2.9 and $0.9 \mathrm{pg} / \mathrm{mL}$ in in vitro P-388, respectively (Tatematsu et al., 1991).

Furthermore, Table 2 presented the preparation and administration of the medicinal plants for the treatment of cancer. The most frequent method of preparation in the study area is by decoction as shown in Table 2. All the plants are grinded to powdered form before either dispersing in water or milk for drinking or either mix with shear butter or water and applied on the affected part of the body.

\section{CONCLUSION}

It was observed that Dutsin-Ma LGA has species of plants for the treatment of cancer. The plants were also corroborated by other literatures as having anti-cancer agent. The utilization of herbal products is associated with educational level, time, point of diagnosis, it looks as if most of the TMPs are satisfy with their prognosis i.e. the use of these plants. It is imperative for ethnobotanists and chemists to establish the toxicity and efficacy of these medicinal plants identified scientifically. The primary challenge in the utilization of herbal remedies is the lack of appropriate quantification and standardization, quality control, good safety measures as well as adulteration with orthodox medicine (WHO, 1998, 2003). Our medical health practitioners should also focus attention on more cancer and tumour research on medicinal plants which can save the lives of our people.

\section{REFERENCES}

Adesina S. K. (2008). Traditional medicine care in Nigeria. Today Newspaper: Wednesday, 23, April 2008.

Ampitan T. A. (2013). Ethnobotanical survey of medicinal plants in Biu local government area of Borno state, Nigeria. Comprehensive Journal of Herbs and Medicinal Plants, 2(1): 7 $-11$.

Mbaveng A. T., Damen F., Mpetga J. D. S., Awouafack M. D., Tane P., Kuete V. and Efferth T. (2019). Cytotoxicity of Crude Extract and Isolated Constituents of the Dichrostachys cinerea Bark towards Multifactorial Drug-Resistant Cancer Cells. Evidence-Based Complementary and Alternative Medicine. Article ID 8450158 ://doi.org/10.1155/2019/8450158.

Burkill H. M. (1995). The useful plants of West Tropical Africa. 2nd ed. Vol. 3. Families J-L. Royal Botanic Gardens, Kew. Pp. 857.
Deeni Y.Y. and Sadiq N. M. (2002). Antimicrobial properties and phytochemical constituents of the leaves of African mistletoe (Tapinanthus dodoneifolius (DC) Danser) (Loranthaceae): an ethnomedicinal plant of Hausaland, Northern Nigeria. J. Ethnopharmacol. 83:235-240.

Eisenberg D, Davis R. and Ettner S (1998). Trends in alternative medicine use in the United States 1990-1997; results of a follow up survey. Journal of American Medical Association, 280: 15691575.

Tatematsu H., Mom M., Yang T-H., Chang J-J., Lee T. T-Y and Lee K-H (1991). Cytotoxic Principles of Securinega virosa: Virosecurinine and Viroallosecurinine and Related Derivatives. Journal of Pharmaceutical Sciences, 80(4): 325-328

Independent News (2017). The Alarming Rate of Cancer Deaths in Nigeria. Published on March 13, 2017. Retrieved from http://www. The Alarming Rate of Cancer Deaths in Nigeria Independent Newspapers Limited March 22, 2017.html

Kumar R. S., Rajkapoor B. and Perumal P. (2011). In vitro and in vivo anticancer activity of Indigofera cassioides Rottl. Ex. DC. Asian Pac J Trop Med., 4:379-385.

Ochwang'i, D.O., Charles N. Kimwele, Jemimah A. Oduma, Peter K. Gathumbi, James M. Mbaria, Stephen G. K. (2013). Medicinal plants used in treatment and management of cancer in Kakamega County, Kenya. Journal of Ethnopharmacology, http://dx.doi.org/10.1016/j.jep.2013.11.051i

Ojewole J. A. O. (2004). Evaluation of the analgesic, antiinflammatory and antidiabetic properties of Sclerocarya birrea (A. Rich.) Hochst. Stem bark aqueous extract in mice and rats. Phytotherapy Research, 18: 601-608.

Olapade E. O (2002). The herbs for good health: the 50th Anniversary Lecture of the University of Ibadan. NARL Specialist Clinic, Ibadan, Nigeria. Pp. 230.

Rayanil K. O., Bunchornmaspan P. and Tuntiwachwuttikul P. (2011). A new phenolic compound with anticancer activity from the wood of Millettia leucantha. Arch Pharm Res., 34:881-886.

Ngulde S. I., Sandabe U. K., Abounader R., Dawson T. K., Zhang Y., Iliya I. and Hussaini I. M. (2019). Ethanol Extract of Securidaca longipedunculata InducesApoptosis in Brain Tumor (U87) Cells. BioMed Research International, Article ID 9826590, https://doi.org/10.1155/2019/982659

Salem M. M., Davidorf F. H. and Abdel-Rahman M. H. (2011). In vitro anti-uveal melanoma activity of phenolic compounds from the Egyptian medicinal plant Acacia nilotica. Fitoterapia 82:1279-1284. 
Soladoye M. O., Amusa N. A, Raji-Esan S. O., Chukwuma E. C. and Taiwo, A. A. (2010). Ethnobotanical Survey of AntiCancer Plants in Ogun State, Nigeria. Annals of Biological Research, 1(4): 261-273.

Traore R (2000). Etude pharmacologique chez l'animal de l'extrait aqueux de Tapinanthus dodoneifolius (DC). Danser (Loranthaceae) utilisée en tradithérapieanti-asthmatique au Burkina Faso. Thèse de pharmacie. FSS. Université d'Ouagadougou, Burkina Faso.
WHO (2018). Cancer Key facts published on 12 September 2018. Retrieved from http://www.who.int/news-room/factsheets/detail/cancer on 22 September, 2018.

WHO (2003). World Health Organization. Traditional medicine 〈http://www.who.int/mediacentre/factsheets/fs 134/en/print.html (revised 2008).

WHO (2010). "Cancer"/http://www.who.int/mediacentre/factsheets/fs297/en/ J(Retrieved 2011-01-05)

Table 1: Identification of medicinal plants, used by traditional medicine practitioners (TMP's) as anticancer agent in the study area

\begin{tabular}{|c|c|c|c|c|c|c|}
\hline $\mathbf{S} / \mathbf{N}$ & Voucher No & Hausa Name & Botanical/Scientific Name & Family name & English name & Parts Used \\
\hline 1. & 6782 & Sanya & Securidaca longipedunculata & Polygalaceae & Violet Tree & Roots \\
\hline 2. & 1342 & Madachi & Khaya ivorensis & Meliaceae & Balsam tree & Bark \\
\hline 3. & 1614 & Maje & Daniellia oliveri & $\begin{array}{l}\text { Leguminosae } \\
\text { caesalpinoirea }\end{array}$ & Doka & Bark \\
\hline 4. & 1532 & Goga Masu & Mitracarpus scaber & Rubiaceae & Mitracarp & Whole plant \\
\hline 5. & 5211 & Bagaye & Cadaba Farinosa & & Cadaba & Roots \\
\hline 6. & 3221 & Kaucin Bagaruwa & Tapinanthus voltensis & Loranthaceae & Mistletoe & Whole plant \\
\hline 7. & 6319 & Dundu & Dichrostachys cinerea & $\begin{array}{l}\text { Leguminosae } \\
\text { mimosoideae }\end{array}$ & Double flower & Roots \\
\hline 8. & 5441 & Kaucin Kalga & Topinanthus dodoneifolius & Loranthaceae & Mistletoe & Whole plant \\
\hline 9. & 8494 & Kaucin Kadanya & Topinanthus dodoneifolius & Loranthaceae & Mistletoe & Whole plant \\
\hline 10. & 5404 & Gamji & Ficus platyphylla & Moraceae & Fig tree & Bark \\
\hline 11. & 1781 & Tsamiya & Tamarindus indica & Leg: Caesalpinoideae & Tamarind & Bark \\
\hline 12. & 1911 & Runhu & Senna singueana & Leg: Caesalpinoideae & Sinq senna & Seeds \\
\hline 13. & 9598 & Gawo & Acacia albida & $\begin{array}{l}\text { Leguminosae } \\
\text { mimosoideae }\end{array}$ & Fodder tree & Bark \\
\hline 14. & 8079 & Sansami & Stereospermum kunthianum & biognoniaceae & Kunths stereosperm & Bark \\
\hline 15 & 2011 & Dorawa & Parkia biglobosa & Leg: mimosoideae & Locust bean tree & Bark, seeds \\
\hline 16 & 6119 & Shirinya & Ficus iteophylla & Moraceae & Tiny leaved fig & Bark \\
\hline 17 & 2025 & Rai dore & Senna occidentalis & Leg: caesalpinoideae & Coffea senna & Whole plant \\
\hline 18 & 9010 & Auduga (karmo) & Gossypium persicum & Malvaceae & Wild cotton & Fruits \\
\hline 19 & 6052 & Busurun Fadama & Hyptis pecutinata & Lamiaceae & Pectinate hyptis & Whole plant \\
\hline 20 & 1491 & Bokai & Eragorastis Tenella & Poaceae & Love grass tiny & Whole plant \\
\hline 21 & 2016 & Sabara (Galls) & Guiera senegalensis & combretaceae & Senegal guiera & Fruits \\
\hline 22 & 5154 & Fasarfafu & Sida cardifolia & Malvaceae & Broom weed & Leaves \\
\hline 23 & 8013 & Tarauniya & Combretum collinum & Combretaceae & $\begin{array}{l}\text { Collinum } \\
\text { combretum }\end{array}$ & Leaves \\
\hline 24 & 2520 & Sawun dawa & Sorghum tricolour & Poaceae & Guinea corn & Roots \\
\hline 25 & 3725 & $\begin{array}{l}\text { Kauchin } \\
\text { sarkakiya }\end{array}$ & Tapinanthus voltensis & Loranthaceae & Mistletoe & Whole plant \\
\hline 26 & 7591 & Daddawar guna & Cucumeropsis & Cucurbitaceae & & Seeds \\
\hline 27 & 1216 & Ginadan Daji & Annona senegalensis & Annonaceae & Custard apple & Leaves \\
\hline 28 & 4577 & Zazar giwa & Hygrophila auriculata & Acanthaceae & Auricul hygrophila & Whole plant \\
\hline 29 & 6613 & Tunya & Euphorbia desmondii & Euphorbiaceae & Desmond euphorbia & Leaves \\
\hline 30 & 2356 & Kukuki & Sterculia setgera & Sterculiaceae & Setiger sterculia & Fruits \\
\hline 31 & 1617 & Kaucin sarkakiya & Tapinanthus globiferus & Loranthaceae & Mistletoe & Whole plant \\
\hline 32 & 1113 & Kakaya & Triumphetta cordifolia & Tiliaceae & Triumphetta & Leaves \\
\hline 33 & 8294 & Dashi & Commiphora pendunculat & Burseraceae & Commiphora & Bark \\
\hline 34 & 4403 & Taruri & Parinari curatellifolia & chrysobalanaceae & Parinary & Seeds \\
\hline 35 & 9099 & Algaris & Nigella sativa & Apiaceae & Black seed & Seeds \\
\hline 36 & 2217 & Hannu & Steganotonia aralliaece & Aralliaceae & & Bark \\
\hline 37 & 4048 & Kwaro Faru & Lannea acida & Anacadiaceae & & Seeds \\
\hline 38 & 3031 & Tsa gwiwar kare & Securinega virosa & Euphorbiacea & & Roots \\
\hline 39 & 1610 & Dakwara & Acacia polyarcantha & Leguminosae & & Leaves \\
\hline 40 & 9062 & Turen gulbi & Cyperus articulatae & Cyperaceae & & Whole plant \\
\hline
\end{tabular}




\begin{tabular}{llllll}
\hline $\mathbf{4 1}$ & 9095 & Fataka & Perugularia tomentosa & Asclepidaceae & Whole plant \\
$\mathbf{4 2}$ & 6430 & Marke & Annogeissus leiocanpus & Combretaceaae & Stem \\
\hline
\end{tabular}

Table 2: Preparation and Administration of medicinal plants used by traditional medicine practitioners (TMP's) as anticancer agent in the study area

\begin{tabular}{|c|c|c|c|c|c|}
\hline $\mathbf{S} / \mathbf{N}$ & $\begin{array}{l}\text { Voucher } \\
\text { No }\end{array}$ & Hausa Name & Botanical/Scientific Name & Family name & Preparation/Administration \\
\hline 1. & 6782 & Sanya & Securidaca longepedunculata & Polygalaceae & $\begin{array}{l}\text { Powdered and make a paste with minimum } \\
\text { amount of water and apply on affected part }\end{array}$ \\
\hline 2. & 1342 & Madachi & Khaya ivorensis & Meliaceae & $\begin{array}{l}\text { Powdered and make a paste with minimum } \\
\text { amount of water and apply on affected part }\end{array}$ \\
\hline 3. & 1614 & Maje & Daniellia oliveri & $\begin{array}{l}\text { Leguminosae } \\
\text { caesalpinoirea }\end{array}$ & $\begin{array}{l}\text { Powdered and mix with shear butter as } \\
\text { ointment and apply on affected part }\end{array}$ \\
\hline 4. & 1532 & Goga Masu & Mitracarpus scaber & Rubiaceae & $\begin{array}{l}\text { Powdered and make a paste with minimum } \\
\text { amount of water and apply on affected part }\end{array}$ \\
\hline 5. & 5211 & Bagaye & Cadaba Farinosa & & $\begin{array}{l}\text { Powdered and make a paste with minimum } \\
\text { amount of water and apply on affected part }\end{array}$ \\
\hline 6. & 3221 & Kaucin Bagaruwa & Tapinanthus voltensis & Loranthaceae & $\begin{array}{l}\text { Powdered and make a paste with minimum } \\
\text { amount of water and apply on affected part }\end{array}$ \\
\hline 7. & 6319 & Dundu & Dichrostachys cinerea & Leg: mimosoideae & Powdered and suspended in water and drink \\
\hline 8. & 5441 & Kaucin Kalga & Topinanthus dodoneifolius & Loranthaceae & $\begin{array}{l}\text { Powdered and make a paste with minimum } \\
\text { amount of water and apply on affected part }\end{array}$ \\
\hline 9. & 8494 & Kaucin Kadanya & Topinanthus dodoneifolius & Loranthaceae & $\begin{array}{l}\text { Powdered and make a paste with minimum } \\
\text { amount of water and apply on affected part }\end{array}$ \\
\hline 10. & 5404 & Gamji & Ficus platyphylla & Moraceae & $\begin{array}{l}\text { Powdered and suspended in water and use } \\
\text { for bath }\end{array}$ \\
\hline 11. & 1781 & Tsamiya & Tomarindus indica & $\begin{array}{l}\text { Leguminosae } \\
\text { Caesalpinoideae }\end{array}$ & Powdered and suspended in water and drink \\
\hline 12. & 1911 & Runhu & Senna sinqueana & $\begin{array}{l}\text { Leguminosae } \\
\text { Caesalpinoideae }\end{array}$ & $\begin{array}{l}\text { Powdered and make a paste with minimum } \\
\text { amount of water and apply on affected part }\end{array}$ \\
\hline 13. & 9598 & Gawo & Acacia albida & $\begin{array}{l}\text { Leguminosae } \\
\text { mimosoideae }\end{array}$ & $\begin{array}{l}\text { Powdered and make a paste with minimum } \\
\text { amount of water and apply on affected part }\end{array}$ \\
\hline 14. & 8079 & Sansami & Stereospermum kunthianum & biognoniaceae & $\begin{array}{l}\text { Powdered and make a paste with minimum } \\
\text { amount of water and apply on affected part }\end{array}$ \\
\hline 15 & 2011 & Dorawa & Parkia biglbosa & $\begin{array}{l}\text { Leguminosae } \\
\text { mimosoideae }\end{array}$ & $\begin{array}{l}\text { Powdered and make a paste with minimum } \\
\text { amount of water and apply on affected part }\end{array}$ \\
\hline 16 & 6119 & Shirinya & Ficus iteophylla & Moraceae & Powdered and suspended in water and drink \\
\hline 17 & 2025 & Rai dore & Senna occidentalis & Leg: caesalpinoideae & $\begin{array}{l}\text { Powdered and make a paste with minimum } \\
\text { amount of water and apply on affected part }\end{array}$ \\
\hline 18 & 9010 & Auduga (karmo) & Gossypium persicum & Malvaceae & $\begin{array}{l}\text { Powdered and make a paste with minimum } \\
\text { amount of water and apply on affected part }\end{array}$ \\
\hline 19 & 6052 & Busurun Fadama & Hyptis pecutinata & lamiaceae & Powdered and burn as incense \\
\hline 20 & 1491 & Bokai & Eragorastis Tenella & Poaceae & $\begin{array}{l}\text { Powdered and make a paste with minimum } \\
\text { amount of water and apply on affected part }\end{array}$ \\
\hline 21 & 2016 & Sabara (Galls) & Guiera senegalensis & combretaceae & $\begin{array}{l}\text { Powdered and make a paste with minimum } \\
\text { amount of water and apply on affected part }\end{array}$ \\
\hline 22 & 5154 & Fasarfafu & Sida cardifolia & malvaceae & $\begin{array}{l}\text { Powdered and make a paste with minimum } \\
\text { amount of water and apply on affected part }\end{array}$ \\
\hline 23 & 8013 & Tarauniya & Combretum collinum & Combretaceae & $\begin{array}{l}\text { Powdered and make a paste with minimum } \\
\text { amount of water and apply on affected part }\end{array}$ \\
\hline 24 & 2520 & Sawun dawa & Sorghum tricolour & Poaceae & $\begin{array}{l}\text { Powdered and make a paste with minimum } \\
\text { amount of water and apply on affected part }\end{array}$ \\
\hline 25 & 3725 & Kauchin sarkakiya & Tapinanthus voltensis & Loranthaceae & $\begin{array}{l}\text { Powdered and make a paste with minimum } \\
\text { amount of water and apply on affected part }\end{array}$ \\
\hline 26 & 7591 & Daddawar guna & Cucumeropsis & Cucurbitaceae & $\begin{array}{l}\text { Powdered and make a paste with minimum } \\
\text { amount of water and apply on affected part }\end{array}$ \\
\hline 27 & 1216 & Ginadan Daji & Annona senegalensis & annonaceae & $\begin{array}{l}\text { Powdered and make a paste with minimum } \\
\text { amount of water and apply on affected part }\end{array}$ \\
\hline 28 & 4577 & Zazar giwa & Hygrophila auriculata & acanthaceae & $\begin{array}{l}\text { Powdered and make a paste with minimum } \\
\text { amount of water and apply on affected part }\end{array}$ \\
\hline 29 & 6613 & Tunya & Euphorbia desmondii & Euphorbiaceae & $\begin{array}{l}\text { Powdered and make a paste with minimum } \\
\text { amount of water and apply on affected part }\end{array}$ \\
\hline 30 & 2356 & Kukuki & Sterculia setgera & Sterculiaceae & $\begin{array}{l}\text { Powdered and make a paste with minimum } \\
\text { amount of water and apply on affected part }\end{array}$ \\
\hline
\end{tabular}




\begin{tabular}{|c|c|c|c|c|c|}
\hline 31 & 1617 & Kaucin sarkakiya & Tapinanthus globiferus & loranthaceae & $\begin{array}{l}\text { Powdered and make a paste with minimum } \\
\text { amount of water and apply on affected part }\end{array}$ \\
\hline 32 & 1113 & Kakaya & Triumphetta cordifolia & Tiliaceae & $\begin{array}{l}\text { Powdered and mix with potash, then a paste } \\
\text { with minimum amount of water and apply on } \\
\text { affected part }\end{array}$ \\
\hline 33 & 8294 & Dashi & Commiphora pendunculat & Burseraceae & $\begin{array}{l}\text { Powdered and make a paste with minimum } \\
\text { amount of water and apply on affected part }\end{array}$ \\
\hline 34 & 4403 & Taruri & Parinari curatellifolia & chrysobalanaceae & $\begin{array}{l}\text { Powdered and make a paste with minimum } \\
\text { amount of water and apply on affected part }\end{array}$ \\
\hline 35 & 9099 & Algaris & Nigella sativa & Apiaceae & $\begin{array}{l}\text { Powdered and make a paste with minimum } \\
\text { amount of water and apply on affected part }\end{array}$ \\
\hline 36 & 2217 & Hannu & Steganotonia aralliaece & aralliaceae & Powdered and suspended in water and drink \\
\hline 37 & 4048 & Kwaro Faru & Lannea acida & Anacadiaceae & Powdered and burn as incense \\
\hline 38 & 3031 & Tsa gwiwar kare & Securinega virosa & euphorbiacea & Powdered and suspended in milk and drink \\
\hline 39 & 1610 & Dakwara & Acacia polyarcantha & leguminosae & $\begin{array}{l}\text { Powdered and make a paste with minimum } \\
\text { amount of water and apply on affected part }\end{array}$ \\
\hline 40 & 9062 & Turen gulbi & Cyperus articulatae & cyperaceae & Powdered and burn as incense \\
\hline 41 & 9095 & Fataka & Perugularia tomentosa & Asclepidaceae & $\begin{array}{l}\text { Powdered and make a paste with minimum } \\
\text { amount of water and apply on affected part }\end{array}$ \\
\hline 42 & 6430 & Marke & Annogeissus leiocanpus & Combretaceaae & $\begin{array}{l}\text { Powdered and make a paste with minimum } \\
\text { amount of water and apply on affected part }\end{array}$ \\
\hline
\end{tabular}

